\title{
Telonema antarcticum sp. nov., a common marine phagotrophic flagellate
}

Correspondence

Dag Klaveness

dag.klaveness@bio.uio.no

\author{
Dag Klaveness, ${ }^{1}$ Kamran Shalchian-Tabrizi, ${ }^{1}$ Helge Abildhauge Thomsen, ${ }^{2}$ \\ Wenche Eikrem ${ }^{1}$ and Kjetill S. Jakobsen ${ }^{1}$ \\ ${ }^{1}$ Department of Biology, University of Oslo, PO Box 1066 Blindern, N-0316 Oslo, Norway \\ ${ }^{2}$ Department of Botany, University of Copenhagen, Øster Farimagsgade 2D, \\ DK-1353 København K, Denmark
}

\begin{abstract}
Telonema is a widely distributed group of phagotrophic flagellates with two known members. In this study, the structural identity and molecular phylogeny of Telonema antarcticum was investigated and a valid description is proposed. Molecular phylogeny was studied using small-subunit rRNA (SSU rRNA) gene sequences. The pear-shaped cell had two subequal flagella that emerged laterally on the truncated antapical tail. One flagellum had tripartite hairs. The cell was naked, but had subsurface vesicles containing angular paracrystalline bodies of an unknown nature. A unique complex cytoskeletal structure, the subcortical lamina, was found to be an important functional and taxonomic feature of the genus. Telonema has an antero-ventral depression where food particles are ingested and then transferred to a conspicuous anterior food vacuole. The molecular phylogeny inferred from the SSU rRNA gene sequence suggested that Telonema represents an isolated and deep branch among the tubulocristate protists.
\end{abstract}

\section{INTRODUCTION}

From a critical analysis of the cellular organization of the protists, Patterson (1994) expected about 80 or more distinct 'ultrastructural identities' to be recognized. However, novel or unexpected patterns of cellular organization are still being discovered. Despite the fact that most critical taxa of protists in culture have been sequenced at the small-subunit (SSU) rRNA level and that the number of genes available for phylogenetic inferences is increasing, the relationships between the major protist branches are still uncertain (e.g. Baldauf et al., 2000; Cavalier-Smith, 2004; Keeling, 2004). There are still hundreds of residual genera that have not yet been investigated by modern methods and therefore have not yet been assigned to any of the known groups [for examples see Patterson, 1999 (Table 3); Patterson et al., 2000; Cavalier-Smith, 2003; Massana et al., 2004]. Further progress depends on the successful establishment of cultures, axenic if possible, to facilitate ultrastructural and molecular investigations. This may also permit critical investigations of physiological characteristics of phylogenetic interest. Eventually, this molecular and structural information may

Published online ahead of print on 17 June 2005 as DOI 10.1099/ ijs.0.63652-0.

Abbreviations: EM, electron microscopy; LM, light microscopy; ML, maximum-likelihood; MP, maximum-parsimony; SSU rRNA, smallsubunit rRNA.

The GenBank/EMBL/DDBJ accession number for the small-subunit rRNA gene sequence of Telonema antarcticum is AJ564773. be converted into phylogenetic information and 'faithfully translated' into classification as suggested by Patterson (1994).

The genus investigated here, the monotypic genus Telonema with Telonema subtilis Griessmann 1913 as the only member with a validly published name, was first described from crude cultures of Ulva and of red algae established in artificial sea water. Cells were colourless, with dorsiventral asymmetry and with few visible inclusions; food inclusions were not seen. Cell size was given as $3-4 \times 6-8 \mu \mathrm{m}$ and the flagella (of body length and drawn as equal) were directed backwards during swimming. A sequel to the rather fragmentary original description came with the thorough light microscopy investigation by Hollande \& Cachon (1950), where state-of-the-art staining techniques resolved cytological details such as flagellar rootlets, a 'bandelette trichocystique' and an apical food vacuole. The size of their organism $(4-6 \times 6-8 \mu \mathrm{m})$ compared well with that of the original description (see above) and an improved diagnosis of the genus Telonema was included.

The first electron micrograph of a thin section of T. subtilis, where the particular identity of the genus was recognized, came with the admirable investigation of Vørs (1992a) of samples collected from the Tvärminne archipelago, Finland. Sections of similar cells in material collected from nature, but not explicitly identified, are present in publications by Sieburth et al. (1988) and Nagasaki et al. (1993). Vørs (1992a) extended the size range of $T$. subtilis to $2-6 \times$ 4-14 $\mu \mathrm{m}$, but named the pointed end of the cell 'anterior' in 
spite of its variable and often posterior direction during swimming (Vørs, 1992a). According to N. Vørs, the pointed end, the 'snout', contains a cytostome and a tubular cytopharynx. This statement does not fully agree with the observations of Hollande \& Cachon (1950), who observed an antero-ventral 'dépression cytostomienne'.

A second, larger species of Telonema, 10-20 $\mu \mathrm{m}$ in diameter and with longer, unequal flagella, was detected by Vørs (1992a) but mentioned only briefly and with reference to unpublished material by Thomsen. Thomsen (1992) made a provisional description of 'Telonema inedit. antarctica', with unequal and heterodynamic flagella (cell size 7-11 $\times 10$ $16 \mu \mathrm{m}$ and flagellar length 9-20 and 13-40 $\mu \mathrm{m}$ ). Its ultrastructure, as judged from a single picture, was very similar to that of T. subtilis but during swimming one flagellum was directed backwards, while the other circumscribed the cell body and provided rotation. Observations on 'T. antarctica Thomsen in Vørs 1992', by Tong (1997), depicted a small $(3 \cdot 5-8 \mu \mathrm{m})$ reniform cell with a rather faint likeness to Thomsen's species. Vørs' 'Telonema subtile', on the other hand, had a size range of $6-20 \times 4-12 \mu \mathrm{m}$, closer to ' $T$. inedit. antarctica' (Thomsen, 1992).

T. subtilis has been observed in the North Atlantic (Throndsen, 1969; Patterson et al., 1993), from Arctic and Antarctic marine waters (Vørs, 1992a, b), the Mediterranean (Griessmann, 1913; Hollande \& Cachon, 1950; Massana et al., 2004), the Baltic Sea (Vørs, 1992a), off the shores of Japan (Throndsen, 1983), in the equatorial Pacific (Vørs et al., 1995) and at Sydney, Australia (Tong et al., 1998). The larger species, ' $T$. inedit. antarctica', was first found in the Antarctic and was later observed throughout the year in Danish waters by Thomsen (1992). This species is common in the Skagerrak-Kattegat area (Karlson \& Kuylenstierna, 2005). Buchanan (1966), in his thesis on plankton from British Columbia, described a flagellate in sufficient detail for it to be recognized as identical to ' $T$. inedit. antarctica'.

In this study, we also use samples taken from the coastal waters of Norway. Despite the fact that the genus Telonema is one of the most widely reported colourless marine flagellates (eurythermal and euryhaline according to its distribution; Vørs, 1992a), very little structural information and genetic data are available for phylogenetic investigations of the genus. Nevertheless, attempts have been made to place Telonema into the phylum Opalozoa by Cavalier-Smith (1993a) and later in Neomonada and the subphylum Isomita (Cavalier-Smith, 1997). More recently, environmental samples (Romari \& Vaulot, 2004) and combinations with culturing (Massana et al., 2004) have provided Telonemalike partial gene sequences.

In this work, the provisionally described species ' $T$. inedit. antarctica' was examined and more details of cellular structure and organization are described. In addition, the fulllength SSU rRNA gene was sequenced and used to infer a molecular phylogeny. A revised description of Thomsen's
' $T$. inedit. antarctica', here named Telonema antarcticum, is presented.

\section{METHODS}

Sampling, culturing and microscopy. Surface sea water samples from the inner Oslo fjord were mixed with a culture of Rhodomonas sp., giving a density of the latter sufficient to stimulate potential grazers. A Telonema sp. appeared in several samples and was isolated by capillary pipetting into cultured suspensions of Rhodomonas in enriched sea-water f/2 (Guillard \& Ryther, 1962) or IMR/2 (Eppley et al., 1967) media. It was transferred regularly into pregrown cultures of the same Rhodomonas. The culture was not bacteria-free but standard sterile techniques and sterile glass equipment were used throughout. The cultures were maintained at $17^{\circ} \mathrm{C}$ on a $14 / 10 \mathrm{~h}$ light/dark cycle.

Growth studies and size/volume estimations were performed in suspensions of Rhodomonas held under the conditions described above. Growth rates of Telonema were estimated after transfer into dense but still growing cultures of Rhodomonas. The individual cell sizes and densities of both eukaryote members were determined by measurements and counting under a microscope or automatically by video recording and the use of imaging software as described later.

The Antarctic material originated from the R/V Polarstern EPOS leg2 cruise (November 1988-January 1989). The target area for this expedition was the Weddel Sea $\left(57-62^{\circ} \mathrm{S} 45-50^{\circ} \mathrm{W}\right)$. In preparation for processing, the nanoplankton was concentrated by centrifugation at ambient temperatures. Whole mounts for electron microscopy (EM) were prepared according to Moestrup \& Thomsen (1980). Grids were shadow-cast with chromium or gold/palladium. The best fixation of cells for sectioning was found in material from station $173\left[49^{\circ} 00 \cdot 7^{\prime} \mathrm{W}\right.$ $59^{\circ} 30.0^{\prime} \mathrm{S}$; temperature at $10 \mathrm{~m}, 0.05^{\circ} \mathrm{C}$; salinity at $10 \mathrm{~m}, 33.45$ practical salinity units (PSU)]. The fixation protocol involved an initial fixation of $2 \mathrm{~h}$ in $2 \%$ glutaraldehyde solution buffered by $0.1 \mathrm{M}$ cacodylate adjusted with $0.5 \mathrm{M}$ sucrose. Post-fixation in $1 \% \mathrm{OsO}_{4}$ for $4 \mathrm{~h}$ was followed by dehydration in ethanol and embedding in Spurr's resin via propylene oxide.

The culture material held in the laboratory was studied by standard light microscopy (LM) or fluorescence microscopy (FLM) techniques using Nikon microscopes. Pictures were taken using black and white (B/W) or colour photography (F301; Nikon) or by greyscale video recording with a B/W COHU CCD camera and IP-Lab imaging software on a Power Macintosh 8100/110 computer. Cells for staining were fixed with EM-grade glutaraldehyde and also stained with DAPI for DNA (Porter \& Feig, 1980). For scanning electron microscopy (SEM), the cells were fixed in $2 \%$ glutaraldehyde in $0 \cdot 1 \mathrm{M}$ sodium cacodylate/ $0 \cdot 01 \mathrm{M} \mathrm{CaCl}_{2}$ buffer $\mathrm{pH} 7 \cdot 4$, post-fixed in $1 \% \mathrm{OsO}_{4}$ in buffer, rinsed, dehydrated in alcohol and critical-point dried using $\mathrm{CO}_{2}$. The SEM was a JSM 6400 (JEOL). For transmission electron microscopy (TEM), cells were fixed in $4 \%$ glutaraldehyde in filtered sea-water or in buffer as above and post-fixed in $1 \% \mathrm{OsO}_{4}$ with $1.5 \%$ $\mathrm{K}_{4} \mathrm{Fe}(\mathrm{CN})_{6}$ added in $0.2 \mathrm{M}$ sodium cacodylate buffer, or a conventional method was used with cacodylate buffer with or without ruthenium red in the primary fixative (Klaveness, 1973).

Ultrathin sections were made on LKB microtomes. Staining procedures depended on the fixation techniques employed. The field material from the Antarctic and the conventionally fixed cultured material were double-stained with uranyl acetate and lead citrate. Cultured material fixed with added $\mathrm{K}_{4} \mathrm{Fe}(\mathrm{CN})_{6}$ was stained in suspension with uranyl acetate in distilled water before dehydration. Some of the sections from blocks fixed with ruthenium red were not stained further in order to 
differentiate the polysaccharides which specifically bind to the ruthenium red. TEM was performed using model 100 SX, 100CX and 1200EX (JEOL) machines.

The EM films were digitalized by a scanner at 1200 d.p.i. and transferred to .psd format in Adobe Photoshop. This program was used to mount plates, locate letters and arrows and clean up dirty backgrounds outside the periphery of the cells.

The Danish material (Thomsen, 1992) was collected from a permanent station located in the Southern Kattegat at $56^{\circ} 15 \cdot 42^{\prime} \mathrm{N}$ and $12^{\circ} 00 \cdot 12^{\prime}$ E. The sampling period was October 1988-December 1989. Material from West Greenland (Trier, 1998; H. A. Thomsen and H. Trier, unpublished data) was obtained from a cruise with the Greenlandic R/V Adolf Jensen (26 June-5 July 1996).

DNA isolation, PCR and DNA sequencing. The T. antarcticum culture from the Oslo fjord was harvested at the exponential phase by centrifugation at $3000 \mathrm{~g}$ for $5 \mathrm{~min}$. DNA was isolated by using a DNA DIRECT kit (Dynal A.S.) as previously described (Rudi et al., 1997). The complete SSU gene was amplified using universal PCR primers (Medlin et al., 1988) with the following conditions: 10 pmol primers, $200 \mu \mathrm{M}$ dNTPs, $10 \mathrm{mM}$ Tris/ $\mathrm{HCl}\left(\mathrm{pH} 8 \cdot 8\right.$ ), $1.5 \mathrm{mM} \mathrm{MgCl}_{2}$, $50 \mathrm{mM} \mathrm{KCl}, 0 \cdot 1 \%$ Triton X-100, $1 \mathrm{U}$ DynaZyme thermostable DNA polymerase (Finnzymes Oy) and 5-10 ng DNA; giving a total volume of $50 \mu \mathrm{l}$. The PCR amplifications were carried out with a initial predenaturation of $5 \mathrm{~min}$ at $94{ }^{\circ} \mathrm{C}$ and followed by 35 cycles of $30 \mathrm{~s}$ at $94^{\circ} \mathrm{C}, 30 \mathrm{~s}$ at $54^{\circ} \mathrm{C}, 2 \mathrm{~min}$ and $30 \mathrm{~s}$ at $72^{\circ} \mathrm{C}$ and a final elongation step at $72{ }^{\circ} \mathrm{C}$ for 7 min (GeneAmp 2400 PCR system; Perkin Elmer).

PCR products were verified by electrophoresis and subsequently cloned with the pGEM R-T vector system and Escherichia coli JM109 competent cells (Promega). Full-length SSU rRNA sequences were generated from clones using six previously described primers (Elwood et al., 1985; Medlin et al., 1988) and a Thermo-Sequenase kit with ${ }^{33}$ P-labelled dideoxynucleotides (Amersham Pharmacia Biotech). The DNA sequences generated were verified by sequencing of both strands of the gene provided by additional PCR amplifications of independent DNA samples.

Alignment and phylogenetic studies. The T. antarcticum SSU rRNA gene sequence was aligned using CLUSTAL_X (Thompson et al.,
1997) with a wide range of taxa from the majority of protist phyla. After manual editing, the alignment consisted of 1178 characters and 46 species.

Phylogenetic analyses were performed with distance and parsimony methods by using PAUP (Swofford, 1998). LogDet distances were calculated by removing identical sites proportionally to base frequencies estimated from constant sites only. The proportion of invariable sites ( pinvar $=0 \cdot 311545$ ) was estimated with the maximum-likelihood (ML) optimality criterion from a neighbour-joining (NJ) tree with Kimura two-parameter (K2P) distances. The ML-distance model estimated from the $\mathrm{K} 2 \mathrm{P}$ tree included a general time reversible substitution matrix (rmatrix $=1 \cdot 09798,2 \cdot 41547,1 \cdot 22801,0 \cdot 70504$, $4 \cdot 05807,1 \cdot 00000$ ), base frequencies (basefreq $=0 \cdot 272078,0 \cdot 208456$, $0 \cdot 279206,0 \cdot 240260)$ and one category proportion of invariable site (pinvar $=0 \cdot 114247$ ) and gamma shape distribution of site rate variation $(\Gamma=0 \cdot 512548)$. Both the LogDet tree and the ML-distance tree were generated with the NJ algorithm. Maximum-parsimony (MP) phylogeny was inferred by reweighting characters according to the rescaled consistency index. MP tree searches were performed by heuristic approach with ten random sequence additions and tree dissection-reconnection (TBR) branch swapping. The robustness of all distance and MP trees was tested using 100 bootstrap pseudoreplicates and tree searches similar to the initial search.

\section{RESULTS}

\section{Surface morphology of Telonema antarcticum}

The body of phagotrophic cells identified as Telonema sp. (Fig. 1a-d) measured 9-15 $\times 6-12 \mu \mathrm{m}$ when fixed with Lugol's solution. Living cells varied considerably in shape and size, depending upon food availability (Table 1).

Well-fed cells were broadly ovoid, nearly spherical and with a short 'tail' from where the two subequal flagella appeared (Fig. 1a, d). They were not unlike J. Schiller's Entomosigma (Schiller, 1925) or H. A. Thomsen's 'T. inedit. antarctica' (Thomsen, 1992) in outline. Unfed cells were slim and sometimes arrow-like, not unlike slim individuals of

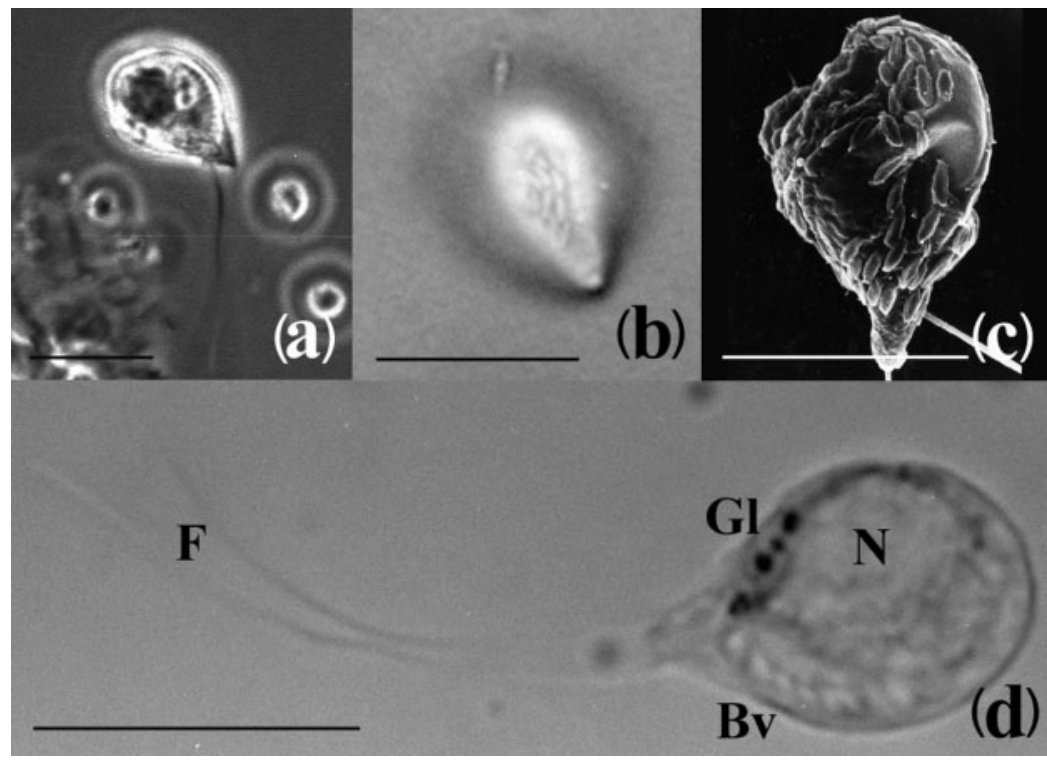

Fig. 1. Various aspects of the whole Telonema antarcticum cell as seen by LM (a, b, d) and SEM (c). (a) Cell as frequently seen after Lugol fixation and sedimentation in the Utermøhl chamber (40/0.65 phase contrast). (b) Surface of living cell as seen by maximum resolution in the light microscope (Apochromat 100/1.40 bright field). The cell surface is coated with bacteriasized objects, which by SEM (c) are revealed as bilateral lanceolate surface structures, termed 'angular paracrystalline objects'. (d) Light micrograph of fixed cell showing the nucleus $(N)$, the lateral band of vesicles $(\mathrm{Bv})$, stainable globules $(\mathrm{Gl})$ and the two flagella (F) emerging diagonally, close to the protruding 'tail' (a bacterium, out of focus, is located between them). Bars, $10 \mu \mathrm{m}$. 
Table 1. Size of Telonema cells under exponential growth conditions, in one case with a large food surplus, and under 'stationary' conditions with no more food available

The first measurement was done by light microscopy, the rest by video recording and the IP-Lab imaging software.

\begin{tabular}{|llccc|}
\hline Culture phase & Method & Number & Major axis $(\boldsymbol{\mu m})$ & Minor axis $(\boldsymbol{\mu m})$ \\
\hline Exponential & Microscopy & 6 & $12 \cdot 4$ & $8 \cdot 1$ \\
Exponential & IP-Lab & 30 & $10 \cdot 7 \pm 1 \cdot 8$ & $8 \cdot 0 \pm 1 \cdot 6$ \\
Exponential with food surplus & IP-Lab & 33 & $12 \cdot 7 \pm 1 \cdot 8$ & $9 \cdot 5 \pm 1 \cdot 1$ \\
Stationary & IP-Lab & 31 & $10 \cdot 5 \pm 1 \cdot 9$ & $7 \cdot 5 \pm 2 \cdot 2$ \\
\hline
\end{tabular}

Oxyrrhis marina Dujardin under starving conditions, but the movements were slower and wiggling compared with those of Oxyrrhis. The Telonema in this study regularly swims with the two flagella directed backwards in a smooth and slowly rotating advance. Single cells may suddenly change direction and then swim swiftly and regularly, in the normal manner, in the opposite direction. They can undergo rapid rotation, indicating a quick shift in the mode of the flagellar beat (Thomsen, 1992).

Standard LM revealed a pyriform cell with two subequal flagella (Fig. 1a, d). Inside the cell, a large nucleus is present (Figs 2 and 3a). A food vacuole, the size of which depends upon the feeding state, may be located anterio-laterally to the nucleus (Figs 2 and 3a). From the position of the food vacuole, a band of $8-10$ smaller vesicles with a refractile content follows the lateral contour of the cell to the beginning of the antapical tail (Fig. 1b). This is possibly the 'bandelette trichocystique' seen by Hollande \& Cachon
(1950), but its function does not appear to be of an ejectile nature. Other cellular inclusions or organelles may be discerned, but not identified, by standard LM on live cells. Cell shape is variable, but most of the variation is observed at the anterior end where the food is taken in and food vesicle formation, digestion and possibly the ejection of residues take place.

By focussing upon the cell surface $(\times 100$ oil, numerical aperture 1.40 bright field optics), surface ornamentations in the shape of small rods could be discerned (Fig. 1b). This compared well with the observations of Buchanan (1966), who found a 'rigid wall with dimpled or punctate surface was discernible in many specimens, and probably present in all'. These structures are also easily recognized by SEM (Fig. 1c). They may be rather scarce (Fig. 2), and cover a smaller or larger part of the cell surface (Fig. 1c), but do not usually cover the entire cell. No glycocalyx could be discerned covering the cell surface by the conventional

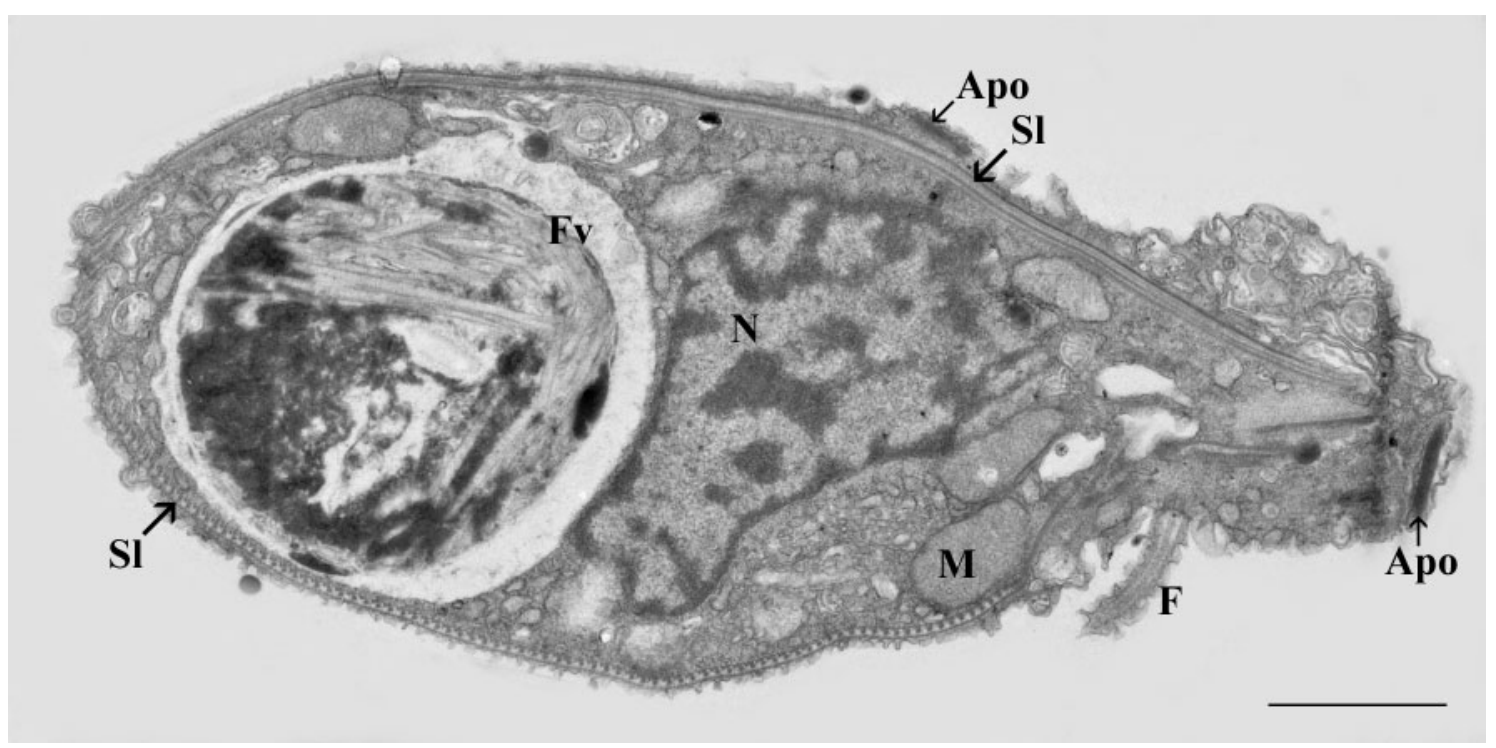

Fig. 2. Section of a cell of Telonema antarcticum showing major structures such as the nucleus (N), mitochondria (M) with tubular cristae and food vacuole (Fv) with residues. The cell content is to a large extent surrounded by a fibrous structure [the subcortical lamina (SI) discussed in the text] associated with the flagellar root area (right) from where the flagella (F) protrude. Under the cell surface, sections of 'angular paracrystalline objects' (Apo) are indicated. Bar, $2 \mu \mathrm{m}$. 


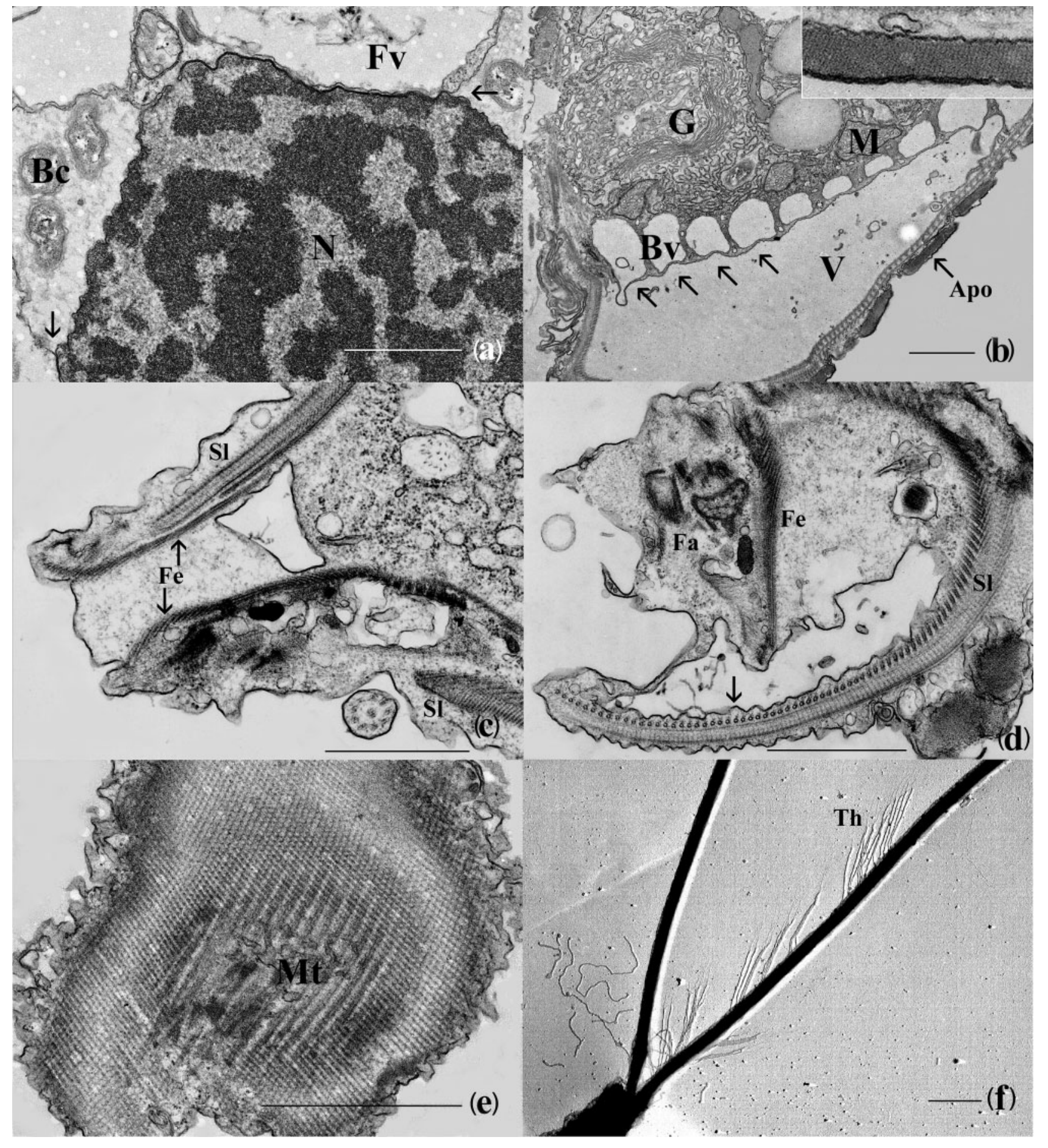

Fig. 3. Details of the ultrastructure of Telonema antarcticum, from wild (c, $d, f)$ and cultured $(a, b, e)$ material. (a) Part of food vesicle $(\mathrm{Fv})$ and nucleus $(\mathrm{N})$ showing the divergence of the nuclear membrane (arrows) into lacunae harbouring bacteria-like objects (Bc). (b) Section of cell in the Golgi $(\mathrm{G})$ region showing a band of vesicles $(\mathrm{Bv})$, of which four are indicated by arrows. Mitochondria (M) are frequently associated with the band of vesicles. The adjacent large contiguous vesicle $(V)$ is also present in many sections. Inset in (b) at top shows the paracrystalline structure of an 'angular paracrystalline object' (Apo). (c) The antapical proboscis sectioned longitudinally showing additional fibrous elements $(\mathrm{Fe})$ inside the subcortical lamina (SI). (d) Section of cell in the flagellar area ( $\mathrm{Fa}$ ), showing the foundation of the subcortical lamina $(\mathrm{SI})$ as a sheet of microtubules (arrow) upon which layers of filaments are located. $\mathrm{Fe}$, Fibrous elements inside the subcortical lamina. (e) A section grazing through the surface of a cell, indicating several layers of filaments alternating between angular and parallel orientation related to the underlying microtubules (Mt). (f) Shadow-cast preparation of whole cell, showing tripartite hairs (Th) on one of the flagella. Bars, $1 \mu \mathrm{m}$. 
fixation and staining procedures employed here (e.g. ruthenium red) for EM. The cell appeared to expose the cell membrane to the environment; it is 'naked'. Beneath the cell membrane, the small rods on the surface appear as a system of paracrystalline structures within vesicles when examined by EM (Figs 2, 3b and inset). These objects probably give rise to the 'dimpled or punctate surface' noted by preceding accidental observers (e.g. Buchanan, 1966) (Fig. 1b, c). Vesicular structures termed 'cortical alveoli' and the products therein are characteristics that are particularly developed within the Alveolata, comprising the Apicomplexa, the ciliates and the dinoflagellates (Cavalier-Smith, 1991, 1993b), but similar structures may also be present elsewhere, as in raphidophytes and glaucophytes (CavalierSmith, 1999).

\section{Ultrastructure}

A closer look at the TEM images revealed a protist with a number of particular characteristics (Figs 2 and 3). The conventional details include the nucleus with reticulate distribution of chromatin (and a nucleolus, not shown) within the double nuclear envelope with pores (Figs 2 and 3a), the mitochondria with tubular cristae (Fig. 3b), the well-developed Golgi with its forming face (cis) against the nuclear envelope, and microbodies or peroxisomes (and some heavily staining spherical bodies, possibly lipids, in some cells, cf. Fig. 1d). A closer look at the doublemembrane nuclear envelope revealed that the outer membrane leaves its inner companion at irregular intervals and forms voluminous lacunae filled with fibrous material (possibly polysaccharide?) in which bacteria-like structures are embedded (Fig. 3a). Bacterial endosymbionts are well known from protists (references in Klaveness, 1982), but the exact location of bacteria within cellular compartments is not always easy to distinguish. A reticulate lacunar network with very few, if any, connections to the outer nuclear envelope forms an endoplasmic reticulum (ER) in Telonema. Expanded areas of the latter also appear to contain bacterialike structures within a fibrous matrix. In many sections, these endoreticular bacteria-like structures (including those of the nuclear envelope) fill $\sim 30 \%$ of the sectioned area of the cell. The extension of the ER itself, with or without associated ribosomes (rough ER or smooth ER), is limited to the proximity of the nucleus in the Telonema cell. The vesicles making up the 'bandelette trichocystique' referred to previously are regularly lined up along one side of the cell (Fig. 3b), but appear empty using standard fixation techniques. Mitochondria with tubular cristae appear to be associated with the vesicles (Fig. 3b). A large vacuole, located laterally and reaching from the posterior 'tail' to the centre of the cell, is often seen both by LM and EM (Fig. 3b, d).

Food particles, in this case cells of Rhodomonas, appear to be taken in at the anterior end of the cell, opposite to the 'tail' described above. The food vesicle remains at the anterior (Fig. 2) or an anterio-lateral side and diminishes with the digestion of the content.
A median section of the cell shows a multilayered complex structure close to the cell surface (Figs 2 and $3 \mathrm{~b}-\mathrm{e}$ ). This multilayered structure is here named the subcortical lamina, apparently an ultrastructural characteristic that is diagnostic for the genus Telonema. The subcortical lamina encloses a major part of the cell's interior and it may consist of more than one piece. Each layer consists of an inner sheet of parallel microtubules, a thick intermediate layer of bands or rods regularly arranged at an angle $\left(80-90^{\circ}\right)$ from the microtubules and an outer layer of filaments interconnected by fibrous matter, with a direction similar to the inner microtubules.

It is apparent that the subcortical lamina makes up a highly dynamic structure. In some images, it appears to be folded to the extent that one area of the lamina is inside another piece of the sheet. How and where it is formed and controlled is of considerable interest. The involvement of microtubules and filamentous and fibrillar material structurally similar to that of the 'flagellar roots' found in several protists suggests that the area of the centrioles where the microtubular organizing centre may be located could be significant.

The major structural details of the Telonema studied here are presented in a simplified schematic reconstruction of a longitudinal dorso-ventral section of the cell (Fig. 4). Further details of flagellar roots, the occasional presence of fibrous bundles of an unknown nature inside the cell and the small spherical structures remain for further study.

\section{Molecular phylogeny}

The phylogenetic inferences based on the SSU rRNA gene sequences, as inferred with MP, are shown in Fig. 5.

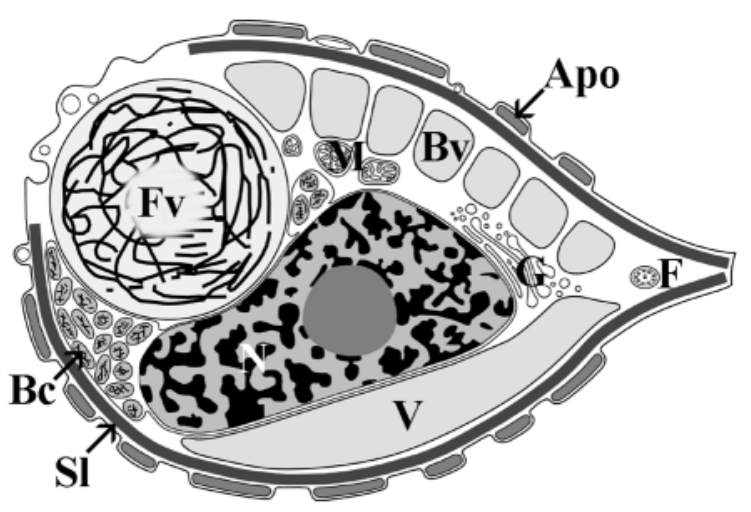

Fig. 4. Schematic and simplistic reconstruction of the essential elements in a hypothetical cell section, depicting critical details discussed in the text and picture legends. Apo, 'Angular paracrystalline objects' inside subsurface membranous sacs, possibly homologous to cortical alveoli. The number appears to be variable, from none to many. Bc, Perinuclear bacteria-like structures. Always present are: $\mathrm{Bv}$, band of vesicles; $\mathrm{F}$, one (of the two) flagella, here shown protruding through the shallow flagellar groove (cf. also Fig. 2); Fv, food vesicle; G, Golgi; M, mitochondria; $\mathrm{N}$, nucleus with nucleolus indicated; $\mathrm{V}$, large vesicle. 


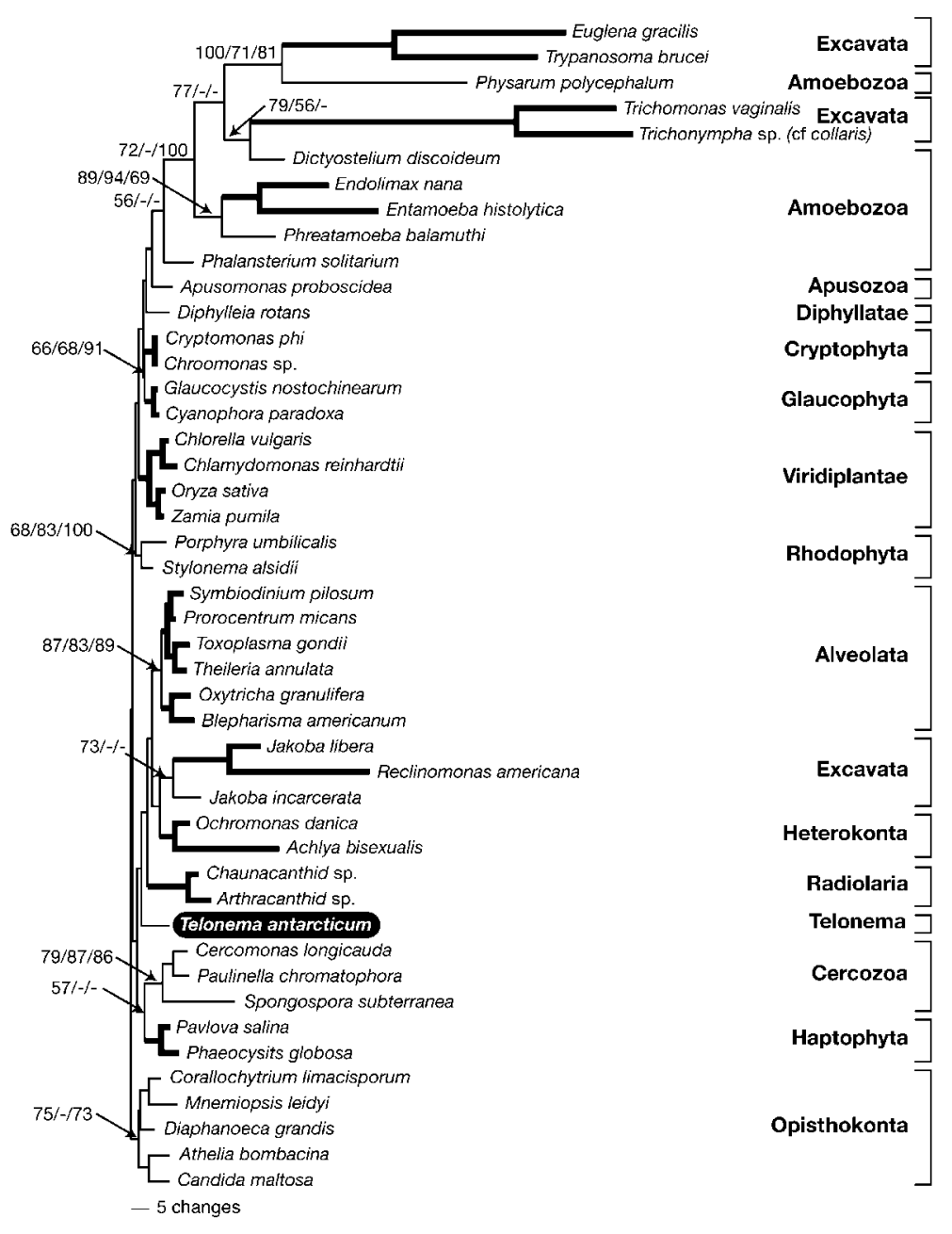

Fig. 5. Phylogeny of $T$. antarcticum based on SSU rRNA gene sequences. The tree is based on MP analysis. Bootstrap values $>70 \%$ from MP, ML-distance and LogDet analyses are indicated at the nodes. The thick branches denote $>90 \%$ support for all bootstrap analyses.
Bootstrap analyses performed with MP, ML distance and LogDet support most of the well-established groups with more than $70 \%$ bootstrap support, but the Excavata and Amoebozoa were polyphyletic. However, the internal nodes in the tree received relatively low bootstrap support with all methods. Importantly, T. antarcticum was never placed in any well-established phyla and the position was always supported by a bootstrap value of $<50 \%$.

\section{The quantitative abundance of $T$. antarcticum}

This species appears to be ubiquitous in most marine habitats, including brackish waters (Vørs, 1992a). In temperate Danish coastal waters (Vørs, 1992c), it is observed throughout most of the year, yet with a conspicuous biomass peak $\left(1-2 \cdot 5 \mu \mathrm{g} \mathrm{C}^{-1}\right)$ in surface waters during late autumn. The type species of the genus Telonema, T. subtilis Griessmann, is more frequently observed in Danish coastal waters (Vørs, 1992c). However, the maximum biomass of this taxon has never been found to exceed $0 \cdot 25 \mu \mathrm{g} \mathrm{C} 1^{-1}$.

Surveys of protist plankton in subarctic West Greenland waters at transects (Trier, 1998; H. A. Thomsen and H. Trier, unpublished results) and at a permanent station sampled throughout the year (H. A. Thomsen and F. Knipschild, unpublished results) have demonstrated a frequent presence of $T$. antarcticum with biomasses typically ranging from 0 to $0 \cdot 25 \mu \mathrm{g} \mathrm{C}^{-1}$ and occasionally reaching $1 \mu \mathrm{g} \mathrm{Cl}^{-1}$. On a few occasions $T$. antarcticum has became the dominant heterotrophic flagellate. In one such incidence, from a Disco Bay transect, T. antarcticum reached a maximum biomass of $6 \cdot 6 \mu \mathrm{g} \mathrm{C}^{-1}$, corresponding to approximately $2 \times 10^{5}$ cells $1^{-1}$. In this particular sample, $T$. antarcticum actually achieved the same biomass as the dinoflagellates which were otherwise found to be the dominant heterotrophic flagellate group in the West Greenland transect survey (Trier, 1998; H. A. Thomsen and H. Trier, unpublished results). A single major biomass peak of $T$. antarcticum was evident in the results from an annual study (1996-1997) of protist plankton at a permanent station in Disco Bay, West Greenland (H. A. Thomsen and F. Knipschild, unpublished results). Approximately 2 weeks after the decline of the diatom spring bloom (approx. $130 \mu \mathrm{g} \mathrm{C}^{-1}$ ), T. antarcticum reached a biomass in excess of $10 \mu \mathrm{g} \mathrm{C}^{-1}$, corresponding to more than $2 \times 10^{5}$ cells $1^{-1}$. 


\section{DISCUSSION}

\section{The subcortical lamina defines the genus Telonema}

The ultrastructure of Telonema allows a distinct 'ultrastructural identity' to be recognized. The subcortical lamina, a multilayered cytoskeleton, appears to be unique to ' $T$. antarcticum' and T. subtilis (Thomsen, 1992) and can thus be considered as a synapomorphic trait for the genus.

The shape of mitochondrial cristae has long been proposed as a reliable character for the classification of eukaryotic superlineages, although some deviating species have been reported (Taylor, 1976, 1999). Flat cristae are usually found among the Opisthokonta (Metazoa, Fungi and Choanoflagellates), the Plantae (Chlorophyta, Rhodophyta and Glaucophyta) and the Cryptophyta lineages, while discoid cristae are characteristic of the euglenoids, kinetoplastid and a few other flagellates (Taylor, 1999). Tubular cristae, which are present in T. antarcticum, are mainly found in alveolates, heterokonts and haptophytes, but some of the cercozoans, foraminifers and excavates also possess such structures (Taylor, 1999; Keeling, 2001). Despite the fact that nuclear rRNA gene sequence phylogeny does not usually reconstruct a clear separation of these mitochondrial lineages, recent molecular phylogenies of other genes (Baldauf et al., 2000) indicate that the type of cristae is a reliable structural characteristic for high-level taxonomy (see discussion in Taylor, 1999). Based on the tubular mitochondrial cristae structure identified in T. antarcticum and the phylogenetic tree where T. antarcticum is weakly associated with groups with tubular cristae, it is possible that the species is related to one of the phyla with such cristal morphology.

In addition, $T$. antarcticum possesses vesicles beneath the outer cell membrane containing 'angular paracrystalline objects' (Apo). The question arises whether these vesicles may have an evolutionary origin in common with the 'cortical alveoli' within alveolates. However, although not highly emphasized in the description of certain heterokont classes and the glaucophytes, other groups may possess similar vacuolar structures to the alveolates (CavalierSmith, 2003). It is a question of whether the alveoli in all these phyla represent homologous structures or have evolved in parallel. Cavalier-Smith (2002) has proposed that cortical alveoli could well have developed before the radiation of the chromalveolates and Plantae. Although the presence of cortical alveoli could lead to the classification of $T$. antarcticum among glaucophytes, we regard the tubular mitochondria cristae in T. antarcticum to preclude any relationship with the glaucophytes. Furthermore, the crystalline structures located inside the subsurface vesicles appear to be unique to Telonema, whereas in dinophyta more or less condensed cellulose plates are assembled within cortical alveoli to form the characteristic armour.

\section{Molecular phylogeny and unique cytoskeleton suggest Telonema as a member of a new eukaryote lineage}

Previous attempts to use SSU rRNA gene sequences to resolve relationships among several of the main protist groups have usually been obstructed by partially contradictory tree topologies and insufficient statistical support (Cavalier-Smith, 2003). Nevertheless, the SSU rRNA gene sequence has been shown to be useful for inferring the phylogeny of eukaryotic lineages with tubular cristae (e.g. Van de Peer \& De Wachter, 1997). The molecular investigation of $T$. antarcticum in this work clearly excludes the genus from being embedded among any of the other known groups of protist species. This also agrees with the isolated position of Telonema based upon analyses of a partial gene sequence, published by Massana et al. (2004) and Romari \& Vaulot (2004). These results, and the presence of the unique cytoskeleton in both T. antarcticum and T. subtilis, suggest that the genus does not belong to any characterized major branch, but probably constitutes a distinct heterotrophic lineage with tubular mitochondria cristae. It is at present not possible to decide if other suggested heterotrophic protists, such as the Nephromycidae (Cavalier-Smith, 1997), are closely related, since the ultrastructure of the cytoskeleton is insufficiently studied and gene sequences are not yet available. An analysis of Telonema comprising several genes from $T$. antarcticum, $T$. subtilis and several full-length sequences from environmental clone libraries (SSU rRNA gene sequences) has been undertaken (K. Shalchian-Tabrizi and others, unpublished data), indicating that the genus Telonema comprises a group of species that branch off deeply within the bikont lineage of eukaryotes close to the chromalveolate lineage.

\section{Emended description of the genus Telonema Griessmann, 1913, genus emend. (ICZN)}

Phagotrophic and biflagellate protists of pyriform shape with the flagella emerging on opposite sides of a short protruding antapical rostrum. A food vacuole may be located anteriorly at the stout end of cell, in front of the centro-lateral large nucleus. Food uptake in a depression in the antero-ventral region. A characteristic band of vesicles is located laterally. Cell with tubulocristate mitochondria and with a characteristic subcortical lamina of microtubules supporting layers of microfilaments oriented at an angle to each other.

\section{Emended Latin diagnosis of the genus Telonema Griessmann, 1913, genus emend. (ICBN)}

Protista pyriformia phagotrophica et biflagellata flagellis e partibus rostro brevi antapicali protrudenti oppositis emergentibus. Vacuola cibaria in parte cellulae antica crassa saepius posita, ante nucleum magnum centro-lateralem. Receptio cibi in depressione regioniz antero-ventralis. Taenia vesicularum characteristica lateralitre locata. Cellula mitochondriis 
tubulocristatis praedita atque lamina subcorticali characteristica microtubulorum strata microfilamentorum inter se angulo positis sustinenti.

\section{Description of Telonema antarcticum Thomsen, sp. nov.}

Cell ovoid to pyriform, $8-16 \times 6-12 \mu \mathrm{m}$, with two subequal flagella significantly longer than the cell length. Swimming may be slow and wiggling while the flagella are directed backwards, or a rapid movement with rotation while flagella are directed forward and laterally. Cell surface dimpled by inclusions in alveoli. Holotypus: Fig. 1(c).

Syn. Telonema inedit. antarctica, Thomsen 1992.

\section{Latin diagnosis of Telonema antarcticum Thomsen, sp. nov.}

Cellula ovoidea ad pyriformem, 8-16×6-12 $\mu \mathrm{m}$, duobus flagellis subaequalibus longitudinem cellulae significanter superantibus instructa. Natatio interdum tarda et fluctuans flagellis retro directis aut motus celer cum rotatione flagellis prorsum et lateralitre directis. Superficies cellulae paullum depressa inclusionibus alveolorum. Holotypus: Fig. 1(c).

Thus, the two validly described species, T. subtilis, Griessmann 1913 and T. antarcticum Thomsen in Klaveness et al. 2005, differ in size, behaviour and food preferences. $T$. subtilis is small, typically $3-4 \times 6-8 \mu \mathrm{m}$ when seen in plankton samples, the flagella are of nearly equal length (cf. Griessmann, 1913) and it feeds on bacteria-sized particles. T. antarcticum is larger, typically $6-12 \times 8-16 \mu \mathrm{m}$, and devours flagellates and small algae under natural conditions. The two obviously unequal flagella (as seen in the light microscope) may allow a swift change of swimming direction and freedom of motility, sometimes observed in cultures (Thomsen, 1992).

\section{ACKNOWLEDGEMENTS}

The Rhodomonas culture was from Jahn Throndsen's collection of flagellates. Tove Bakar prepared the sections for TEM and Per Færøvig performed the video-based size estimates of the cells. We also wish to thank Joachim Nedreklepp and Torstein Tengs for helpful assistance with the DNA sequencing, Jeffrey D. Silberman for the SSU alignment and Chris Kelly for discussion and critical reading of the manuscript. Bjørg Tosterud translated the diagnoses into Latin. This work was supported by the Norwegian Research Council (grant 121187/720 to D. K. and grant $118894 / 431$ to K. S. J.

\section{REFERENCES}

Baldauf, S. L., Roger, A. J., Wenk-Siefert, I. \& Doolittle, W. F. (2000). A kingdom-level phylogeny of eukaryotes based on combined protein data. Science 290, 972-977.

Buchanan, R. J. (1966). A study of the species composition and ecology of the protoplankton of a British Columbia inlet. $\mathrm{PhD}$ thesis, University of British Columbia, Canada.
Cavalier-Smith, T. (1991). Cell diversification in heterotrophic flagellates. In The Biology of Free-Living Heterotrophic Flagellates (Special publication of The Systematics Association, vol. 45), pp. 113-131. Edited by D. J. Patterson \& J. Larsen. Oxford: Clarendon Press.

Cavalier-Smith, T. (1993a). The protozoan phylum Opalozoa. J Eukaryot Microbiol 40, 609-615.

Cavalier-Smith, T. (1993b). Kingdom Protozoa and its 18 phyla. Microbiol Rev 57, 953-994.

Cavalier-Smith, T. (1997). Amoeboflagellates and mitochondrial cristae in eukaryote evolution: megasystematics of the new protozoan subkingdoms Eozoa and Neozoa. Arch Protistenkd 147, 237-258.

Cavalier-Smith, T. (1999). Principles of protein and lipid targeting in secondary symbiogenesis: euglenoid, dinoflagellate, and sporozoan plastid origins and the eukaryote family tree. J Eukaryot Microbiol 46, 347-366.

Cavalier-Smith, T. (2002). The phagotrophic origin of eukaryotes and phylogenetic classification of Protozoa. Int J Syst Evol Microbiol 52, 297-354.

Cavalier-Smith, T. (2003). Protist phylogeny and the high-level classification of protozoa. Eur J Protistol 39, 338-348.

Cavalier-Smith, T. (2004). Only six kingdoms of life. Proc R Soc Lond B Biol Sci 271, 1251-1262.

Elwood, H. J., Olsen, G. J. \& Sogin, M. L. (1985). The small-subunit ribosomal RNA gene sequences from the hypotrichous ciliates Oxytricha nova and Stylonychia pustulata. Mol Biol Evol 2, 399-410.

Eppley, R. W., Holmes, R. W. \& Strickland, J. D. H. (1967). Sinking rates of marine phytoplankton measured with a fluorometer. $J$ Exp Mar Biol Ecol 1, 191-208.

Griessmann, K. (1913). Über marine Flagellaten. Arch Protistenkd 32 (year 1914), 1-78 (in German).

Guillard, R. R. L. \& Ryther, J. H. (1962). Studies of marine planktonic diatoms. I. Cyclotella nana Hustedt and Detonula confervacea (Cleve) Gran. Can J Microbiol 8, 229-239.

Hollande, A. \& Cachon, J. (1950). Structure et affinités d'un flagellé marin peu connu, Telonema subtilis Griesm. Ann Sci Nat Zool 12, 109-113 (in French).

Karlson, B. \& Kuylenstierna, M. (2005). Plankton database. http:// www.marbot.gu.se/planktondb.html

Keeling, P. J. (2001). Foraminifera and Cercozoa are related in actin phylogeny: two orphans find a home? Mol Biol Evol 18, 1551-1557.

Keeling, P. J. (2004). Diversity and evolutionary history of plastids and their hosts. Am J Bot 91, 1481-1493.

Klaveness, D. (1973). The microanatomy of Calyptrosphaera sphaeroidea, with some supplementary observations on the motile stage of Coccolithus pelagicus. Norw J Bot 20, 151-162.

Klaveness, D. (1982). The Cryptomonas-Caulobacter consortium: facultative ectocommensalism with possible taxonomic consequences? Nord J Bot 2, 183-188.

Massana, R., Balagué, V., Guillou, L. \& Pedrós-Alió, C. (2004). Picoeukaryotic diversity in an oligotrophic coastal site studies by molecular and culturing approaches. FEMS Microbiol Ecol 50, 231-243.

Medlin, L., Elwood, H. J., Stickel, S. \& Sogin, M. L. (1988). The characterization of enzymatically amplified eukaryotic 16S-like rRNA-coding regions. Gene 71, 491-499.

Moestrup, Ø. \& Thomsen, H. A. (1980). Preparation of shadow-cast whole mounts. In Handbook of Phycological Methods, vol. III, pp. 385-390. Edited by E. Gantt. Cambridge: Cambridge University Press. 
Nagasaki, K., Ando, M., Imai, I., Itakura, S. \& Ishida, Y. (1993). Virus-like particles in an apochlorotic flagellate in Hiroshima Bay, Japan. Mar Ecol Prog Ser 96, 307-310.

Patterson, D. J. (1994). Protozoa: evolution and systematics. In Progress in Protozoology, Proceedings of the IX International Congress of Protozoology, Berlin 1993, pp. 1-14. Edited by K. Hausmann \& N. Hülsmann. Stuttgart: Gustav Fischer.

Patterson, D. J. (1999). The diversity of eukaryotes. Am Nat 154 (Suppl. 4), S96-S124.

Patterson, D. J., Nygaard, K., Steinberg, G. \& Turley, C. M. (1993). Heterotrophic flagellates and other protists associated with oceanic detritus throughout the water column in the mid North Atlantic. J Mar Biol Assoc U K 73, 67-95.

Patterson, D. J., Vørs, N., Simpson, A. G. B. \& O’Kelly, C. (2000). Residual free-living and predatory heterotrophic flagellates. In $A n$ Illustrated Guide to the Protozoa, 2nd edn, vol. II, pp. 1302-1328. Edited by J. J. Lee, G. F. Leedale \& P. Bradbury. Lawrence, Kansas: Society of Protozoologists.

Porter, K. G. \& Feig, Y. S. (1980). The use of DAPI for identifying and counting aquatic microflora. Limnol Oceanogr 25, 943-948.

Romari, K. \& Vaulot, D. (2004). Composition and temporal variability of picoeukaryote communities at a coastal site of the English Channel from 18S rDNA sequences. Limnol Oceanogr 49, 784-798.

Rudi, K., Kroken, M., Dahlberg, O. J., Deggerdal, A., Jakobsen, K. S. \& Larsen, F. (1997). Rapid, universal method to isolate PCR-ready DNA using magnetic beads. Biotechniques 2, 506-511.

Schiller, J. (1925). Über die Besiedlung europäischer Meere mit Cryptomonaden und über einen Flagellaten peridineenähnlicher Organisation (Entomosigma peridinioides). Österr Bot Z 74, 194-198 (in German).

Sieburth, J. M., Johnson, P. W. \& Hargraves, P. E. (1988). Ultrastructure and ecology of Aureococcus anophagefferens gen. et sp. nov. (Chrysophyceae): the dominant picoplankter during a bloom in Narragansett Bay, Rhode Island, summer 1985. J Phycol 24, 416-425.

Swofford, D. L. (1998). PAUP: Phylogenetic Analysis Using Parsimony ${ }^{*}$ and Other Methods. Sunderland, MA: Sinauer Associates.

Taylor, F. J. R. (1976). Flagellate phylogeny: a study in conflicts. J Protozool 23, 28-40.
Taylor, F. J. R. (1999). Ultrastructure as a control for protistan molecular phylogeny. Am Nat 154 (Suppl. 4), S125-S136.

Thompson, J. D., Gibson, T. J., Plewniak, F., Jeanmougin, F. \& Higgins, D. G. (1997). The CLUSTAL_X windows interface: flexible strategies for multiple sequence alignment aided by quality analysis tools. Nucleic Acids Res 25, 4876-4882.

Thomsen, H. A. (editor) (1992). Plankton i de Indre Danske Farvande. Copenhagen: Havforskning fra Miljøstyrelsen (in Danish).

Throndsen, J. (1969). Flagellates of Norwegian coastal waters. Nytt Magasin Botanikk 16, 161-216.

Throndsen, J. (1983). Ultra- and nanoplankton flagellates from coastal waters of southern Honshu and Kyushu, Japan (including some results from the western part of the Kuroshio off Honshu). Working Party on Taxonomy in the Akashiwo Mondai Kenkyukai, Fishing Ground Preservation Division, Research Department, Fisheries Agency, Japan, pp. v + 1-62. Japan: Fisheries Agency.

Tong, S. M. (1997). Heterotrophic flagellates and other protists from Southampton water, UK. Ophelia 47, 71-131.

Tong, S. M., Nygaard, K., Bernard, C., Vørs, N. \& Patterson, D. J. (1998). Heterotrophic flagellates from the water column in Port Jackson, Sydney, Australia. Eur J Protistol 34, 162-194.

Trier, H. (1998). Marint phytoplankton i subarktis - kvantitative og kvalitative aspekter. MSc thesis, University of Copenhagen, Denmark (in Danish).

Van De Peer, Y. \& De Wachter, R. (1997). Evolutionary relationships among the eukaryotic crown taxa taking into account site-to-site rate variation in 18 S rRNA. J Mol Evol 45, 619-630.

Vørs, N. (1992a). Heterotrophic amoebae, flagellates and heliozoa from the Tvärminne area, Gulf of Finland, in 1988-1990. Ophelia 36, 1-109.

Vørs, N. (1992b). Heterotrophic amoebas, flagellates and heliozoa from arctic marine waters (North-West-Territories, Canada and West Greenland). Polar Biol 13, 113-126.

Vørs, N. (1992c). Heterotrofe protister (ekskl. dinoflagellater, loricabærende choanoflagellater og ciliater). In Plankton $i$ de Indre Danske Farvande pp. 195-251. Edited by H. A. Thomsen. Copenhagen: Havforskning fra Miljøstyrelsen (in Danish).

Vørs, N., Buck, K. R., Chavez, F. P., Eikrem, W., Hansen, L. E., Østergaard, J. B. \& Thomsen, H. A. (1995). Nanoplankton of the equatorial Pacific with emphasis on the heterotrophic protists. Deep-Sea Res II Top Stud Oceanogr 42, 585-602. 